\title{
Knockdown of immature colon carcinoma transcript 1 induces suppression of proliferation, $S$-phase arrest and apoptosis in leukemia cells
}

\author{
GUANG-YAO LI ${ }^{1,2}$, JI-ZHU LIU ${ }^{2}$, LI ZHANG ${ }^{2}$, GUO-ZHEN LIU ${ }^{2}$, SHUANG-JING LI ${ }^{2}$, TAI-WU XIAO ${ }^{2}$, \\ JING-XIA WANG $^{2}$, LE-XIN WANG ${ }^{3}$ and MING HOU ${ }^{1}$
}

${ }^{1}$ Department of Hematology, Qilu Hospital of Shandong University, Jinan, Shandong 250012; ${ }^{2}$ Department of Hematology, Liaocheng People's Hospital, Liaocheng, Shandong 252000, P.R. China; ${ }^{3}$ School of Biomedical Sciences,

Charles Sturt University, Wagga Wagga, NSW 2650, Australia

Received April 8, 2017; Accepted September 25, 2017

DOI: $10.3892 /$ or.2018.6185

\begin{abstract}
Immature colon carcinoma transcript 1 (ICT1), a human mitochondrial translation release factor, is a ribosomedependent codon-independent peptidyl-tRNA hydrolase. ICT1-deficiency has been recognized as a cell growth inhibitor of hepatoblastoma and glioblastoma multiforme. To explore the role of ICT1 in human leukemia, 2 short hairpin RNAs (shRNAs) targeting ICT1 sequences were designed in leukemia U937 cells. The successful infection of ICT1 in the U937 cells was observed under a fluorescence microscope and further quantified by western blotting and quantitative real-time PCR (qRT-PCR) analysis. Tetrazolium dye (MTT) assay revealed a significant decrease in proliferation of ICT1knockdown U937 cells on the fourth and fifth day as compared with the control. Depletion of ICT1 resulted in an increase in $\mathrm{S}$ phase and sub-G1 (representing cell apoptosis) fractions. Annexin V-APC/7-AAD staining assay confirmed that knockdown of ICT1 played a crucial role in boosting early and late apoptotic programs in U937 cells. Downregulation of ICT1 also altered cyclin A2 transcription expression, caspase-3 activity and p21 protein expression. Additionally, decreased levels of heat shock protein 27 (HSP27) phosphorylation at Ser78 was correlated with knockdown of ICT1 in U937 cells. Thus, we concluded that the regulatory role of ICT1 in leukemia may be used as a potential therapeutic target for the treatment of leukemia.
\end{abstract}

Correspondence to: Professor Ming Hou, Division of Hematology, Qilu Hospital of Shandong University, Shandong, P.R. China

E-mail: houming@medmail.com.cn

Professor Le-Xin Wang, School of Biomedical Sciences, Charles Sturt University, Wagga Wagga, NSW 2678, Australia

E-mail: lwang@csu.edu.au

Key words: leukemia, ICT1, proliferation, cell cycle, apoptosis, caspase- 3 activity

\section{Introduction}

Leukemia is one of the most common hematological cancers worldwide (1). Acute leukemia can be classified into acute lymphoblastic leukemia (ALL) and acute myeloid leukemia (AML) (2). A high incidence of ALL is found in children, and AML is the most common acute leukemia in adults $(1,3)$. Due to the high degree of resistance to standard chemotherapy, older AML patients have a median survival of $\sim 7$ months and the overall 5-year survival is only $5-15 \%(4,5)$. Optimized chemotherapy protocols provide more than $80 \%$ cure rates for childhood ALL (6). ALL patients often have relapses and the prediction of prognosis remains difficult (7). Notably, bone marrow transplantation provides an effective and practical treatment for some patients, However graft-rejection and relapses are the major causes of treatment failure in these patients (8).

Gene therapy targeting cancer cells provide a potential alternative therapeutic strategy for cancer (9). CD40-ligand (CD154) gene therapy increased leukemia-specific $\mathrm{T}$ cells and decreased the number of leukemia cells (10). The proliferative activity of the leukemic cells and the clonogenicity of the primary cells were inhibited by knockdown of polo-like kinase 1 (11). RNA interference (RNAi) targeting knockout of M-BCR/ABL mRNA and oncoprotein kill K562 human leukemic cells (12).

Immature colon carcinoma transcript 1 (ICT1) encodes an essential mitochondrial protein and an integral component of the mitoribosome $(13,14)$. ICT1 was revealed to function as a ribosome-dependent codon-independent peptidyl-tRNA hydrolase (14). It was originally discovered by comparison of gene expression pattern between undifferentiated and differentiated human colon cancer cells (HT29-D4) (13). Lack of ICT1 markedly reduced the number of HeLa and human hepatoblastoma HepG2 cells, and was able to induce HeLa cell apoptosis (13). Akabane et al (15) also demonstrated that mutation of the GGQ-motif of ICT1 led to a loss of cell viability and affected cell growth. Absence of ICT1 inhibited proliferation of glioblastoma multiforme cells through the arrest of the cell cycle at the G2/M phase (16). However, the role of ICT1 in leukemic cancer is unknown. 


\section{Materials and methods}

Cell lines and cell culture. U937 leukemia and human embryonic kidney 293 (HEK293) cells were purchased from the Chinese Academy of Sciences (Shanghai, China). U937 cells were propagated in RPMI-1640 medium (SH30809.01B; HyClone, Logan, UT, USA) with $10 \%$ fetal bovine serum (FBS; 04-001-1A; Biological Industries, Grand Island, NY, USA). HEK293T cells were maintained in Dulbecco's modified Eagle's medium (DMEM; SH30243.01B; HyClone) with $10 \%$ FBS.

Construction and transduction of lentivirus-based vectors. Two independent shRNAs targeting ICT1 were designed from GenBank (accession no. NM_001545). shRNA (S1) and shRNA (S2) sequences for ICT1 (5'-GCTGTTAATGCTTGTC TATAACTCGAGTTATAGACAAGCATTAACAGC-3' and 5'-GCAGAATGTGAACAAAGTGAACTCGAGTTCACTT TGTTCACATTCTGC-3') were inserted into pGP vectors (SBI, Mountain View, CA, USA) at the EcoRI and BamHI sites. ICT1 shRNA scrambled control was: 5'-TTCTCCGAAC GTGTCAC GTCTCGAGACGTGACACGTTCGGAGAA-3'. HEK293T cells were transiently transfected with the mixture of recombinant $\mathrm{pGP}$ vectors, pVSVG-I and pCMVAR8.92 (Sigma, St. Louis, MO, USA) using Lipofectamine 2000 (Invitrogen, Carlsbad, CA, USA), in accordance with the manufacturer's instructions. U937 cells were inoculated at densities of 10,000 cells/well in each of the 12-well plates and infected with lentiviral particles [shCon, shICT (S1) or shICT1 (S2)] at a multiplicity of infection (MOI) of 80. At $168 \mathrm{~h}$ post-infection, the infection efficiency was detected by GFP-positive U937 cells under a fluorescence microscopy.

Quantitative real-time RT-PCR ( $q R T-P C R)$. After transfection for 7 days, total cellular RNA was extracted from U937 cells using TRIzol reagent (Gibco, Grand Island, NY, USA) followed by first-strand cDNA synthesis with the Invitrogen Superscript first-strand system. qRT-PCR analysis was performed on Bio-Rad Connet Real-Time PCR platform using SYBR Premix EX Taq ${ }^{\mathrm{TM}}$ (Takara, Dalian, China). The primer sequences were as follows: ICT1 forward, 5'-CAGCCTGGACAAGCTC TACC-3' and reverse, 5'-GGAACCTGACTTCTGCCTTG-3'; actin forward, 5'-GTGGACATCCGCAAAGAC-3' and reverse, 5'-AAAGGGTGTAACGCAACTA-3'; cyclin A2 forward, 5'-GTTCCTCCTTGGAAAGCAAAC-3' and reverse, 5'-GGGCATCTTCACGCTCTATTT-3'.

The reaction mixture contained $10 \mu 1$ of $2 X$ SYBR Premix Ex Taq, $0.5 \mu 1$ of forward and reverse primers $2.5 \mu \mathrm{M}, 5 \mu \mathrm{l}$ of cDNA, and $4.5 \mu \mathrm{l}$ of $\mathrm{ddH}_{2} \mathrm{O}$. The qRT-PCR parameters were as follows: initial denaturation at $95^{\circ} \mathrm{C}$ for $1 \mathrm{~min}, 40$ cycles of amplification at $60^{\circ} \mathrm{C}$ for $20 \mathrm{~min}$, and final extension at $72^{\circ} \mathrm{C}$ for $10 \mathrm{~min}$. ICT1 gene expression levels were assessed using the $2^{-\Delta \Delta C t}$ method.

Western blotting. For western blotting assay, the U937 cells were infected with lentiviral particles for 6 days. In short, cells were washed twice with ice-cold phosphate-buffered saline (PBS) before being lysed with $1 \mathrm{ml} 2 \mathrm{X}$ SDS sample buffer [100 mM Tris-Hcl (pH 6.8), 10 mM EDTA, 4\% SDS, 10\% glycine]. Supernatants were collected after centrifugation for $20 \mathrm{~min}$ at $12,000 \mathrm{x} \mathrm{g}$. A total $30 \mu \mathrm{g}$ of protein samples in each lane were electrophoresed by $10 \%$ sodium dodecyl sulphate-polyacrylamide gel electrophoresis (SDS-PAGE). Proteins were then transferred onto polyvinylidene difluoride (PVDF) membranes (Millipore, Belfor, MA, USA) under the following conditions: $300 \mathrm{~mA}, 1.5 \mathrm{~h}$. The membranes were incubated overnight at $4^{\circ} \mathrm{C}$ with rabbit anti-ICT1 (cat. no. Ab-147; 1:1,000 dilution; Abgent, San Diego, CA, USA), rabbit anti-caspase-3 (cat. no. 9661; 1:500 dilution; Cell Signaling Technology, Beverly, MA, USA), rabbit anti-p21 (cat. no. Ab-106; 1:1,000 dilution; Santa Cruz Biotechnology, Santa Cruz, CA, USA) and rabbit anti-GAPDH (cat. no. Ab-5; 1:500,000 dilution; ProteinTech Group, Chicago, IL, USA). Finally, secondary antibody horseradish peroxidase (HRP)-conjugated goat anti-rabbit (cat. no. SC2054; Santa Cruz Biotechnology) was applied in a dilution of 1:5,000 at room temperature for $2 \mathrm{~h}$. The membranes were processed using enhanced chemiluminescence (ECL) advance detection reagent.

MTT assay. To determine the viable cell number in U937 cells, the MTT assay was carried out. The shCon, shICT1 (S1) and shICT1 (S2) cells were firstly grown in a 6-well plate at a density of 3,000 cells/well. At various time-points, each sample was mixed with $20 \mu \mathrm{l}$ of $5 \mathrm{mg} / \mathrm{ml} \mathrm{3-(4,5-dimethylthiazol-2-yl)-2,}$ 5 -diphenyltetrazolium bromide and incubated for $2.5 \mathrm{~h}$. The medium was then replaced with $100 \mu \mathrm{l}$ of acidic isopropanol (10\% SDS, $5 \%$ isopropanol and $0.01 \mathrm{~mol} / \mathrm{l} \mathrm{HCl}$ ) to stop the reaction and read at a wavelength of $595 \mathrm{~nm}$ on a microplate reader (Microplate Reader 3550; Bio-Rad, Hercules, CA, USA).

Flow cytometric analysis of the cell cycle. The untransfected and transfected U937 cells were plated at a density of 100,000 cells/well in 12-well tissue culture plates and incubated for 7 days. After being washed in PBS, the cells were fixed overnight at $4^{\circ} \mathrm{C}$ in ice-cold $70 \%$ alcohol. The cells were then stained with $1 \mathrm{ml}$ propidium iodide solution $(0.1 \mathrm{mg} / \mathrm{ml}$ propidium iodide and $20 \mu \mathrm{g} / \mathrm{ml}$ RNaseA DNase-free) at room temperature, $30^{\circ} \mathrm{C}$. Furthermore, the cells were examined by fluorescence-activated cell sorting (FACS) based on flow cytometry (FACSort; Becton-Dickinson, Franklin Lakes, NJ, USA) and the cell cycle distribution was determined using MultiCycle AV software (Phoenix Flow Systems, San Diego, CA, USA).

Apoptotic cell death assay. Comparison of the abilities of shCon and shICT1 (S1) transfection to induce cell apoptosis was assessed using an Annexin V-APC/7-AAD (BD Pharmingen, San Diego, CA, USA) kit according to the instructions of the manufacturer. The level of apoptosis was analyzed on a FACSort flow cytometer. Cells positive for both 7-AAD and Annexin V-APC were late apoptotic cells. Live cells were represented by Annexin V-APC and 7-AAD negative staining. 7-AAD stained cells that were Annexin V-APC negative were considered as necrotic cells. While negative for 7-AAD and positive for Annexin V-APC were early apoptotic cells.

PathScan intracellular signaling array. To detect the potential differences in intracellular signaling between the ICT1 
$\mathbf{A}$
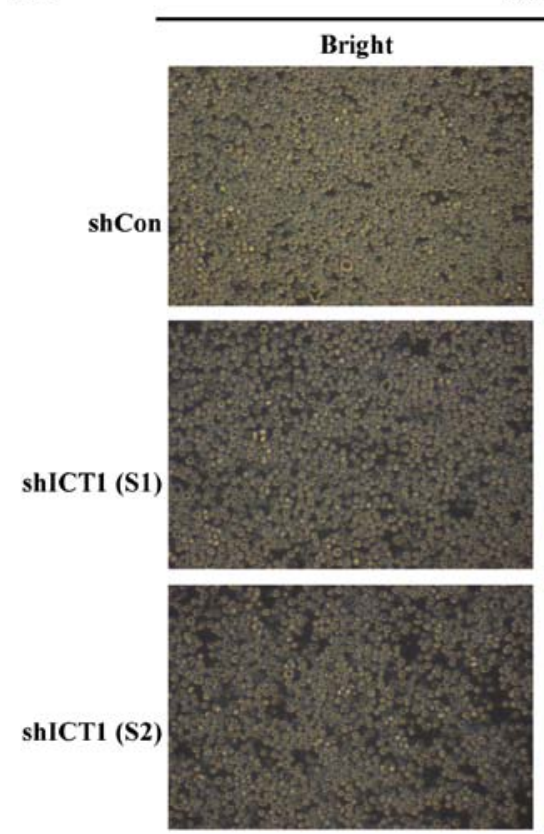

U937
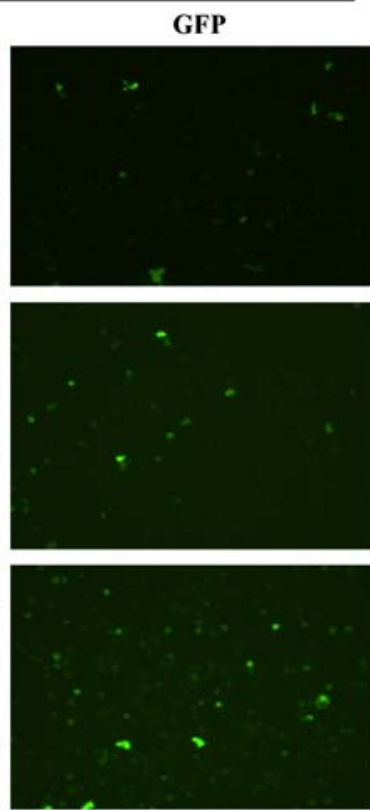

B

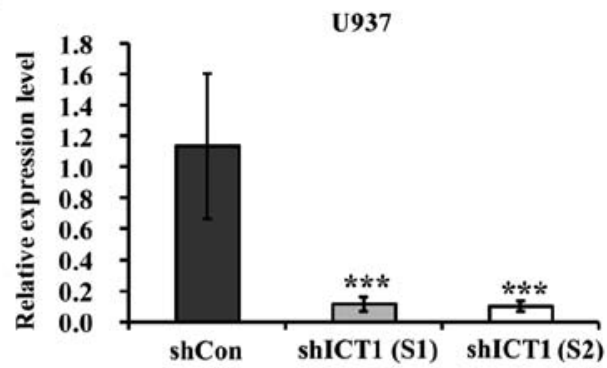

C

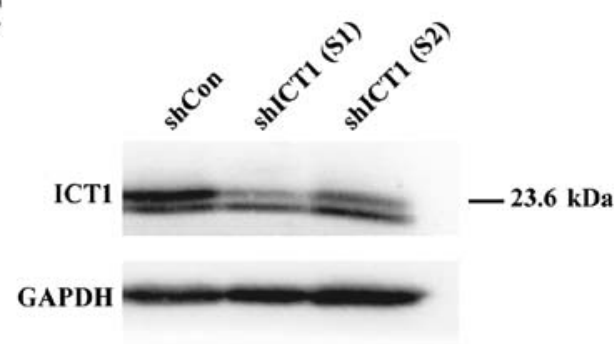

Figure 1. Knockdown of immature colon carcinoma transcript 1 (ICT1) by lentivirus-mediated delivery of shRNA in leukemia U937 cells. (A) Expression of green fluorescent protein (GFP) was obtained under a fluorescence microscope. Infection efficiency was quantified by analyzing GFP-infected cells at $168 \mathrm{~h}$ post-transduction in MOI 80. Scale bars, $25 \mu \mathrm{m}$. (B and C) Both ICT1-shRNA infections decreased ICT1 expression at the transcriptional and translational level, as determined by qRT-PCR and western blotting. Actin and GAPDH were used as normalizing controls for qRT-PCR and western blotting, respectively. All experiments were conducted and analyzed at least 3 times. ${ }^{* * *} \mathrm{P}<0.001$.

knockdown and control cells, the PathScan ${ }^{\circledR}$ intracellular signaling array kit (Cell Signaling Technology) was used, which allows the monitoring of 18 signaling molecules when phosphorylated or cleaved. Samples were processed according to the manufacturer's procedures and the signal intensity was visualized under the LI-COR Odyssey imaging system (LI-COR Biosciences, Lincoln, NE, USA).

Statistical analysis. All data analyses were performed using SPSS software version 16.0 (SPSS, Inc., Chicago, IL, USA). Data are expressed as the mean \pm SD of at least 3 independent experiments. Student's t-test was used to calculate the individual comparisons between different groups. A P-value of $<0.05$ was considered to indicate a statistically significant result.

\section{Results}

ICT1 stable knockdown by lentivirus-based shRNA in U937 cells. The recombinant lentiviruses encoding shCon or shICT1 were constructed to reveal the functional role of ICT1 in leukemia. The lentiviral vectors also carried a GFP reporter gene to monitor the infection efficiency. By counting GFP-positive cells $168 \mathrm{~h}$ after infection, transfection efficiencies of 90.1, 90.0 and $91.2 \%$ were observed in the shCon, shICT1 (S1) and shICT1 (S2) groups, respectively (Fig. 1A).

As shown in Fig. 1B, the ICT1 gene expression pattern in the shICT1 (S1) and shICT1 (S2) cells was lower than that in the shCon cells. Western blotting was applied to detect whether specific lentivirus-mediated shRNA could knockdown ICT1 protein level in U937 cells. The knockdown of ICT1 reduced the ICT1 protein level in U937 cells (Fig. 1C).
U937

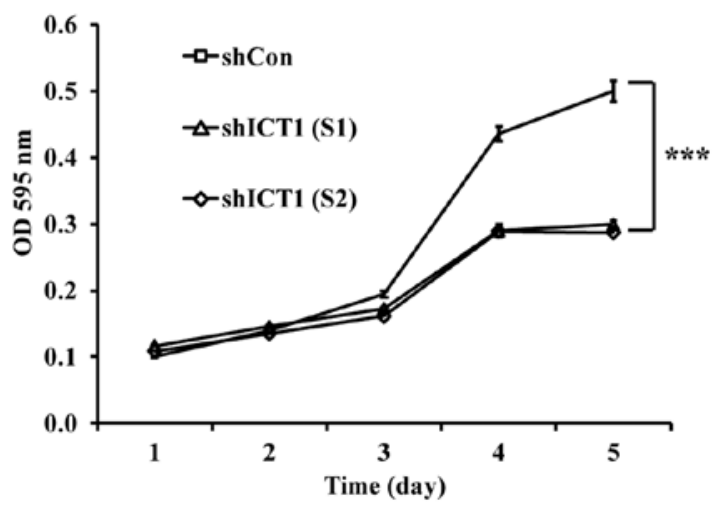

Figure 2. Knockdown of immature colon carcinoma transcript 1 (ICT1) function to block the proliferative capacity of leukemia U937 cells. The shape of the growth curve in U937 cells was assessed by MTT assay 96 h posttransduction. The experiment was conducted and analyzed at least 3 times; ${ }^{* * * *} \mathrm{P}<0.001$

Knockdown of ICT1 inhibits U937 cell proliferation. As shown in Fig. 2, the shICT1 (S1)- or shICT1 (S2)-treated cells had a relatively lower proliferative index from the third day compared with shCon. On the fourth day, the proliferation was reduced by $33.3 \%$ in cells expressing reduced levels of ICT1 in contrast with the control (shCon). On the fifth day, in comparison with the control cultures, proliferation was decreased by 40.2 and $42.6 \%$ for shICT1 (S1)- and shICT1 (S2)-infected U937 cells, respectively.

ICT1 knockdown arrests U937 cells in the Sand sub-G1 phases. Flow cytometry was carried out to determine whether or not 
$\mathbf{A}$

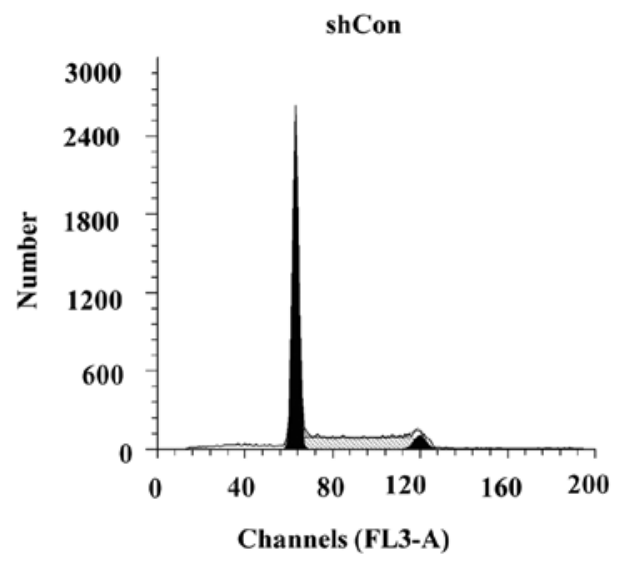

B

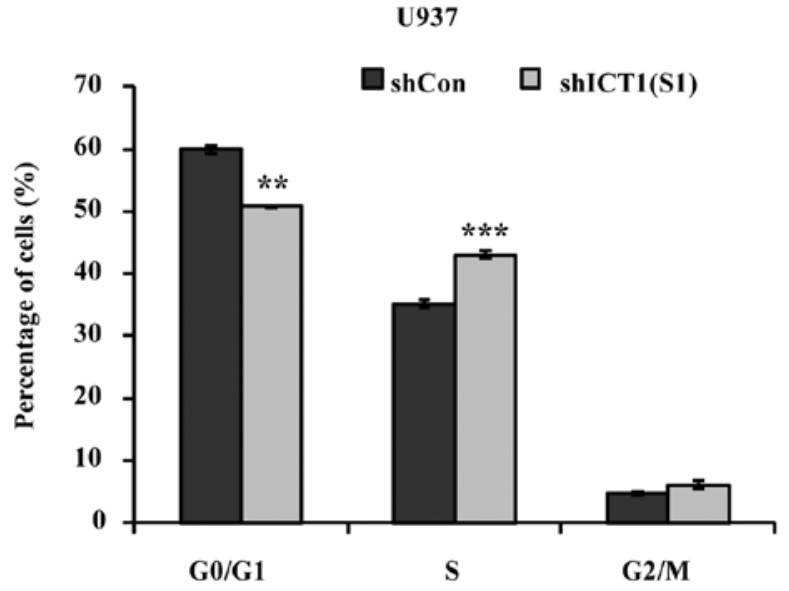

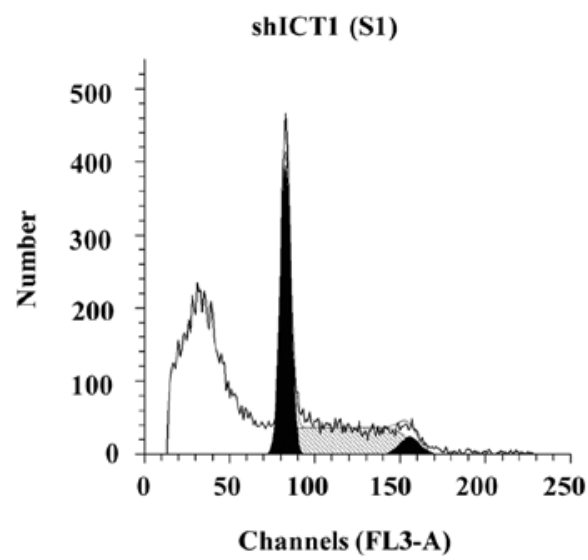

C

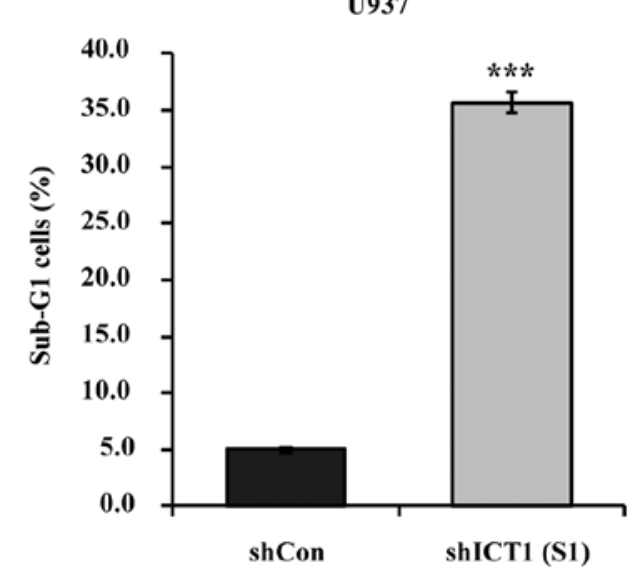

Figure 3. Immature colon carcinoma transcript 1 (ICT1) deficiency causes growth arrest in the S phase and increases apoptotic sub-G1 population of leukemia U937 cells. (A) The cell cycle distribution in U937 cells deficient or with no deficiency in ICT1 was assayed by flow cytometry. (B) The percentage of cells was decreased in G0/G1 phase, but increased in the S phase of shICT1 (S1) cells in contrast to the shCon groups. (C) Loss of ICT1 produced a significant build-up of apoptotic (sub-G1) cells. The experiments were conducted and analyzed at least 3 times; ${ }^{* *} \mathrm{P}<0.01 ;{ }^{* * * *} \mathrm{P}<0.001$.

deficiency of ICT1 can interfere with cell cycle progression in U937 cells (Fig. 3A). As shown in Fig. 3B, the percentage of G0/G1 phase cells decreased from $60.0 \%$ in the shCon-treated group to $50.8 \%$ in the shICT1 (S1)-treated group. Increased percentage of S-phase cells occurred in the shICT1 (S1) group with $43.5 \%$ compared with $35.2 \%$ in shCon-treated group. There was no statically significant difference in the G2/M phase between the shCon and shICT1 (S1) groups.

U937 cells transfected with shICT1 (S1) resulted in an enhanced sub-G1 (representing apoptotic cells) fraction (Fig. 3C). The sub-G1 population of U937 cells represented only $5.02 \%$ in shCon, but reached $\sim 35.70 \%$ upon infection with lentiviral vectors expressing shICT1 (S1).

Effect of deficiency on ICT1 expression on the apoptosis in U937 cells. A marked sub-G1 peak was observed in ICT1-deficient cells. Then Annexin V-APC/7-AAD double labeling was employed to assess whether U937-cell depletion in ICT1 really undergoes apoptosis (Fig. 4A). As shown in Fig. 4B, ICT1 deficiency increased the level of early apoptosis from $4.0 \%$ (shCon-treated cells) to $6.0 \%$ [shICT1 (S1)-treated cells] in the. U937 cells treated with shICT1 (S1) exhibited an increase in late-apoptotic cells compared with control, varying from $15.1 \%$ in cells treated with shICT1 (S1) to $5.9 \%$ in the
Lv-shCon treatment. In addition, the proportion of viable cells was decreased in U937 cells transfected with shICT1 (S1) in comparison with control shCon-transfected cells.

Depletion of ICT1 results in increased cyclin A2 transcription expression. Using qRT-PCR, we analyzed the cyclin A2 mRNA expression in U937 cells transfected with shCon and shICT1, respectively. As observed in Fig. 5, the expression profile of cyclin A2 in the ICT1-knockdown U937 cells was found to have increased by $27.1 \%$ compared with the shCon-transfected cells.

ICT1 downregulation exhibits altered caspase-3 and p21 protein expression in U937 cells. Active 17 and $19 \mathrm{kDa}$ subunits of caspase- 3 were increased in shICT1 (S1) cells as compared to the controls (Fig. 6). The pro-caspase3 protein levels were decreased in U937 cells with ICT1 knockdown compared with the non-knockdown controls. U937 cells depleted of the ICT1 gene were also found to be decreased in the expression level of p21 protein.

Decreased levels of heat shock protein 27 phosphorylation at Ser78 was correlated with knockdown of ICT in U937 cells. The expression of 18 phosphorylated or cleaved signaling molecules was assessed using the PathScan Intracellular 
$\mathbf{A}$

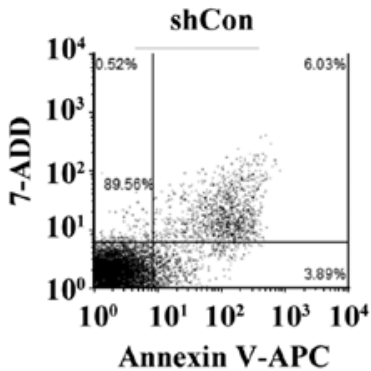

B

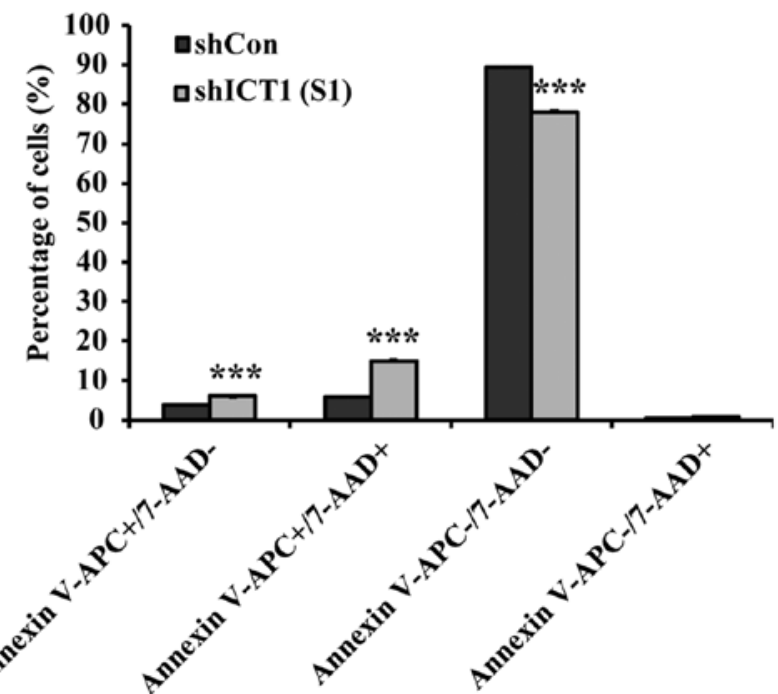

Figure 4. Early and late apoptotic events induced by knockdown of immature colon carcinoma transcript 1 (ICT1) in U937 cells. (A) Apoptotic cells were evaluated by Annexin V-APC/7-AAD double labeling with flow cytometry. (B) After transfection for 7 days, depletion of ICT1 resulted in more susceptible leukemia U937 cells to early and late apoptosis; ${ }^{* * * *} \mathrm{P}<0.001$.

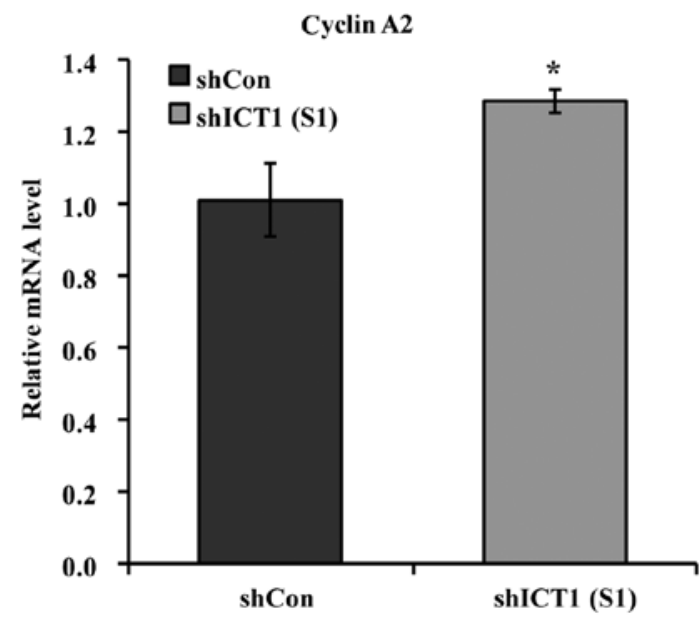

Figure 5. Specific immature colon carcinoma transcript 1 (ICT1) gene depletion induces upregulation of cyclin A2 mRNA in U937 cells. RT-qPCR was employed to detect the relative quantification of cyclin $\mathrm{A} 2 ;{ }^{*} \mathrm{P}<0.05$.

Signaling Array kit. As shown in Fig. 7, Ser78 HSP27 phosphorylation in U937 cells with shICT1 (S1) transduction was lower than that of the shCon cells. The phosphorylation level of other signaling molecules was almost unaltered between the shCon and shICT1 (S1) groups.

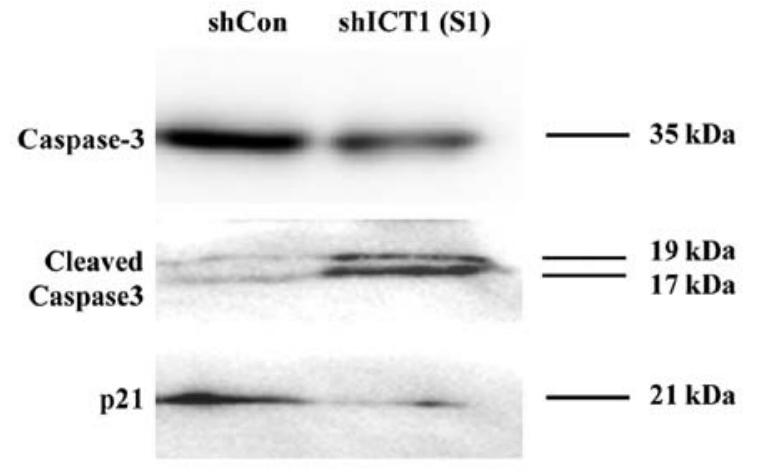

GAPDH

$35 \mathrm{kDa}$

Figure 6. U937 cells expressing shICT1 (S1) accompanied by an increase in caspase-3 and decrease in p21. The appearance of 17- and 19-kDa fragments of caspase-3 was increased, meanwhile, a 35-kDa band was decreased in U937 cells. The p21 protein expression was markedly reduced by the downregulation of ICT1 in U937 cells.

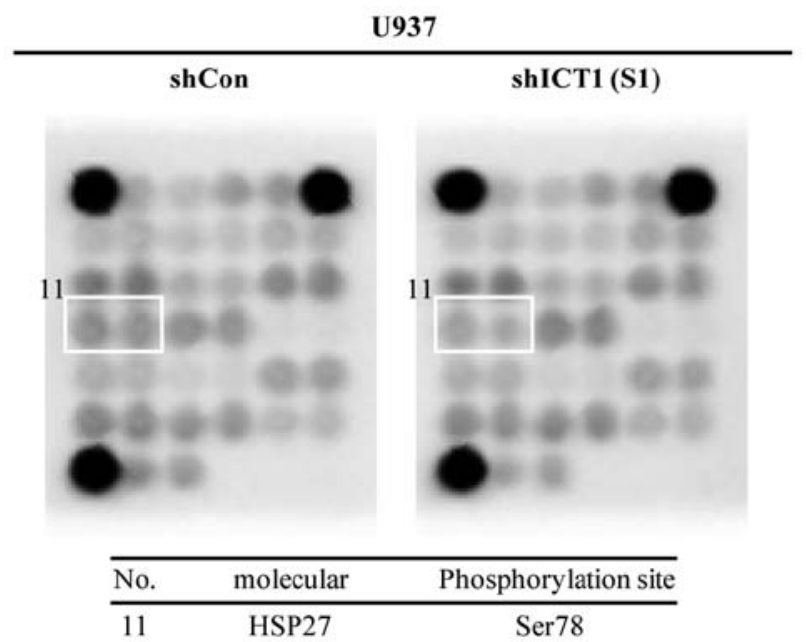

Figure 7. Depletion of immature colon carcinoma transcript 1 (ICT1) hinders HSP27 phosphorylation at the Ser78 site in U937 cells. The phosphorylation status of 18 important signaling molecules was assessed by PathScan ${ }^{\circledR}$ Intracellular Signaling Array kit.

\section{Discussion}

Immature colon carcinoma transcript 1 (ICT1) is a component of human mitoribosome that has codon-independent peptidyltRNA hydrolysis activity through a conserved GGQ motif (13). ICT1 plays a role in the pathogenesis of colon cancer, hepatoblastoma and glioblastoma multiforme but its role in leukemia is unclear $(16,17)$. The present study demonstrated that loss of ICT1 was associated with the inhibition of leukemia cell proliferation, cell cycle arrest and apoptosis.

The cell cycle process is a sequence of events in which one cell divides and then replicates into 2 cells, each containing the information and components necessary to repeat the biological process $(18,19)$. Cyclins, including A, B, C, D and E, are regulatory subunits of cyclin-dependent kinases, forming different cyclin-CDK complexes to monitor cell cycle progression $(20,21)$. Cyclin A2, a member of the subclass of A-type 
cyclins, is synthesized in somatic cells, promoting mitotic entry and regulating G1/S transition through CDK1 and CDK2 $(22,23)$. In the present study, lentivirus-mediated downregulation of the ICT1 gene was able to accelerate cyclin A2 mRNA expression in U937 cells. Tiwari et al (24) found that excessive expression of cyclin A, CDK1 and CDK 2 alone could not activate human $\beta$-cells to enter the cell cycle.p21 is a potent inhibitor of CDKs thus negatively regulating mammalian cell cycle division (25). In the present study, the p21 protein level was decreased in U937 cells with ICT1 knockdown. Thus, the activity of multiple mitotic CDK-cyclin complexes may be influenced as a consequence of increased cyclin A2 mRNA and decreased p21 protein levels. $S$ phase-arrest induced by knockdown of ICT1 may be related to changes in the activity of cyclin/CDK complexes.

Apoptosis or programmed cell death, a physiologically cell killing process, is important for suppression of tumor growth $(26,27)$. Cell apoptosis occurred in HeLa cells where ICT1 had been knockdown by small interfering RNA, with a reduction of mitochondrial membrane potential and mass (13). In the present study, apoptotic cell death in U937 leukemia cells was observed in the ICT1-knockdown group, which was consistent with previous results (13). Waterhouse et al (28) found that cytochrome $c$ emancipation and caspase activation was accompanied with the permeability of the mitochondrial outer membrane during apoptosis. The effector pro-caspase-3 was thought to be cleaved and activated in a condition that was promoted by cytochrome $c$ from mitochondria to monitor cell apoptosis (29). For U937 cells with ICT1 knockdown, strong cleavage/activation of caspase-3 precursor was obtained based on increased formation of 17- and 19-kDa fragments. It is likely that the mitochondrial cytochrome $c$-mediated caspase-3 pathway may be activated, inducing apoptosis in ICT1-knockdown U937 cells.

Overexpression of human chaperone protein HSP27 has been reported to rescue cells from apoptosis induced by oxidative stress or cytotoxicity $(30,31)$. Activity of HSP27 could be modulated by post-translational modification of phosphorylation (32). At present, 3 phosphorylations sites on Ser residues at positions 15, 78 and 82 for human HSP27 have been identified $(32,33)$. Notably, HSP27 acts to protect mitochondrial integrity and prevent cytochrome $c$ release (33). The nonphosphorylated oligomers of HSP27 can directly bind with cytosolic cytochrome $c$ to protect against apoptosis (33). The present study confirmed that Ser78 of HSP27 was less phosphorylated in ICT1-knockdown U937 cells as compared with the control, indicating that more non-phosphorylated oligomers may have accumulated. Therefore, an unknown mechanism may exist to impede interaction between cytochrome $c$ and HSP27, leading to the promotion of cytochrome $c$ release from mitochondria to the cytosol and induction of apoptosis by triggering caspases, such as caspase-3.

In conclusion, the present study demonstrated that proliferation of leukemia U937 cells was blocked after depletion of ICT1. Knockdown of ICT1 was found to induce S-phase arrest, and promote apoptosis possibly via a mitochondrial cytochrome $c$-mediated caspase-3 pathway in leukemia U937 cells. However, the correlation between decreased HSP27 phosphorylation and increased caspase- 3 activation needs further investigation. The newly identified role of ICT1 in leukemia cells in the present study may be useful in the development of new therapies for leukemia.

\section{Acknowledgements}

The present study was supported by the National Natural Science Foundation of China (nos. 81573772 and 81403263), and the Science and Technology Developing Project of Shandong Province (grant no. 2014GSF118141).

\section{References}

1. Mi S, Lu J, Sun M, Li Z, Zhang H, Neilly MB, Wang Y, Qian Z, Jin J, Zhang Y, et al: MicroRNA expression signatures accurately discriminate acute lymphoblastic leukemia from acute myeloid leukemia. Proc Natl Acad Sci USA 104: 19971-19976, 2007.

2. Golub TR, Slonim DK, Tamayo P, Huard C, Gaasenbeek M, Mesirov JP, Coller H, Loh ML, Downing JR, Caligiuri MA, et al: Molecular classification of cancer: Class discovery and class prediction by gene expression monitoring. Science 286: 531-537, 1999.

3. Cortes JE and Kantarjian HM: Acute lymphoblastic leukemia. A comprehensive review with emphasis on biology and therapy. Cancer 76: 2393-2417, 1995.

4. Büchner T, Berdel WE, Haferlach C, Haferlach T, Schnittger S, Müller-Tidow C, Braess J, Spiekermann K, Kienast J, Staib P, et al: Age-related risk profile and chemotherapy dose response in acute myeloid leukemia: A study by the German Acute Myeloid Leukemia Cooperative Group. J Clin Oncol 27: 61-69, 2009.

5. Ziogas DC, Voulgarelis M and Zintzaras E: A network metaanalysis of randomized controlled trials of induction treatments in acute myeloid leukemia in the elderly. Clin Ther 33: 254-279, 2011.

6. Radtke S, Zolk O, Renner B, Paulides M, Zimmermann M, Möricke A, Stanulla M, Schrappe M and Langer T: Germline genetic variations in methotrexate candidate genes are associated with pharmacokinetics, toxicity, and outcome in childhood acute lymphoblastic leukemia. Blood 121: 5145-5153, 2013.

7. Yang JJ, Cheng C, Devidas M, Cao X, Campana D, Yang W, Fan Y, Neale G, Cox N, Scheet P, et al: Genome-wide association study identifies germline polymorphisms associated with relapse of childhood acute lymphoblastic leukemia. Blood 120: 4197-4204, 2012.

8. Locatelli F, Zecca M, Rondelli R, Bonetti F, Dini G, Prete A, Messina C, Uderzo C, Ripaldi M, Porta F, et al: Graft versus host disease prophylaxis with low-dose cyclosporine-A reduces the risk of relapse in children with acute leukemia given HLA-identical sibling bone marrow transplantation: results of a randomized trial. Blood 95: 1572-1579, 2000.

9. McCormick F: Cancer gene therapy: Fringe or cutting edge? Nat Rev Cancer 1: 130-141, 2001.

10. Wierda WG, Cantwell MJ, Woods SJ, Rassenti LZ, Prussak CE and Kipps TJ: CD40-ligand (CD154) gene therapy for chronic lymphocytic leukemia. Blood 96: 2917-2924, 2000.

11. Renner AG, Dos Santos C, Recher C, Bailly C, Créancier L, Kruczynski A, Payrastre B and Manenti S: Polo-like kinase 1 is overexpressed in acute myeloid leukemia and its inhibition preferentially targets the proliferation of leukemic cells. Blood 114: 659-662, 2009.

12. Wilda M, Fuchs U, Wössmann W and Borkhardt A: Killing of leukemic cells with a BCR/ABL fusion gene by RNA interference (RNAi). Oncogene 21: 5716-5724, 2002.

13. Handa Y, Hikawa Y, Tochio N, Kogure H, Inoue M, Koshiba S, Güntert P, Inoue Y, Kigawa T, Yokoyama S, et al: Solution structure of the catalytic domain of the mitochondrial protein ICT1 that is essential for cell vitality. J Mol Biol 404: 260-273, 2010.

14. Richter R, Rorbach J, Pajak A, Smith PM, Wessels HJ, Huynen MA, Smeitink JA, Lightowlers RN and ChrzanowskaLightowlers ZM: A functional peptidyl-tRNA hydrolase, ICT1, has been recruited into the human mitochondrial ribosome. EMBO J 29: 1116-1125, 2010.

15. Akabane S, Ueda T, Nierhaus KH and Takeuchi N: Ribosome rescue and translation termination at non-standard stop codons by ICT1 in mammalian mitochondria. PLoS Genet 10: e1004616, 2014. 
16. Xie R, Zhang Y, Shen C, Cao X, Gu S and Che X: Knockdown of immature colon carcinoma transcript-1 inhibits proliferation of glioblastoma multiforme cells through Gap 2/mitotic phase arrest. Onco Targets Ther 8: 1119-1127, 2015.

17. Aleman MJ, DeYoung MP, Tress M, Keating P, Perry GW and Narayanan R: Inhibition of Single Minded 2 gene expression mediates tumor-selective apoptosis and differentiation in human colon cancer cells. Proc Natl Acad Sci USA 102: 12765-12770, 2005

18. Mitchison JM (ed): The Biology of The Cell Cycle. Cambridge University Press, Cambridge, UK, pp313, 1971.

19. Murray A and Hunt T: The Cell Cycle: An Introduction. Q Rev Biol 2: 147-163, 1995.

20. Buckley MF, Sweeney KJ, Hamilton JA, Sini RL, Manning DL, Nicholson RI, deFazio A, Watts CK, Musgrove EA and Sutherland RL: Expression and amplification of cyclin genes in human breast cancer. Oncogene 8: 2127-2133, 1993.

21. Murray AW, Solomon MJ and Kirschner MW: The role of cyclin synthesis and degradation in the control of maturation promoting factor activity. Nature 339: 280-286, 1989.

22. Chaudhry HW, Dashoush NH, Tang H, Zhang L, Wang X, Wu EX and Wolgemuth DJ: Cyclin A2 mediates cardiomyocyte mitosis in the postmitotic myocardium. J Biol Chem 279: 35858-35866, 2004

23. Bendris N, Lemmers B, Blanchard JM and Arsic N: Cyclin A2 mutagenesis analysis: A new insight into $\mathrm{CDK}$ activation and cellular localization requirements. PLoS One 6: e22879, 2011.

24. Tiwari S, Roel C, Wills R, Casinelli G, Tanwir M, Takane KK and Fiaschi-Taesch NM: Early and late G1/S cyclins and Cdks act complementarily to enhance authentic human $\beta$-cell proliferation and expansion. Diabetes 64: 3485-3498, 2015.

25. Chang MW, Barr E, Lu MM, Barton K and Leiden JM: Adenovirusmediated over-expression of the cyclin/cyclin-dependent kinase inhibitor, p21 inhibits vascular smooth muscle cell proliferation and neointima formation in the rat carotid artery model of balloon angioplasty. J Clin Invest 96: 2260-2268, 1995.
26. Evan GI and Vousden KH: Proliferation, cell cycle and apoptosis in cancer. Nature 411: 342-348, 2001.

27. Strasser A, O'Connor L and Dixit VM: Apoptosis signaling. Annu Rev Biochem 69: 217-245, 2000.

28. Waterhouse NJ, Goldstein JC, von Ahsen O, Schuler M, Newmeyer DD and Green DR: Cytochrome $c$ maintains mitochondrial transmembrane potential and ATP generation after outer mitochondrial membrane permeabilization during the apoptotic process. J Cell Biol 153: 319-328, 2001.

29. Liu X, Zou H, Slaughter C and Wang X: DFF, a heterodimeric protein that functions downstream of caspase-3 to trigger DNA fragmentation during apoptosis. Cell 89: 175-184, 1997.

30. Huot J, Houle F, Spitz DR and Landry J: HSP27 phosphorylationmediated resistance against actin fragmentation and cell death induced by oxidative stress. Cancer Res 56: 273-279, 1996.

31. Garrido C, Schmitt E, Candé C, Vahsen N, Parcellier A and Kroemer G: HSP27 and HSP70: Potentially oncogenic apoptosis inhibitors. Cell Cycle 2: 579-584, 2003.

32. Yasuda E, Kumada T, Takai S, Ishisaki A, Noda T, MatsushimaNishiwaki R, Yoshimi N, Kato K, Toyoda H, Kaneoka Y, et al: Attenuated phosphorylation of heat shock protein 27 correlates with tumor progression in patients with hepatocellular carcinoma. Biochem Biophys Res Commun 337: 337-342, 2005.

33. Landry J, Lambert H, Zhou M, Lavoie JN, Hickey E, Weber LA and Anderson CW: Human HSP27 is phosphorylated at serines 78 and 82 by heat shock and mitogen-activated kinases that recognize the same amino acid motif as S6 kinase II. J Biol Chem 267: 794-803, 1992. 